\title{
AGE OF MUD BRECCIA FROM MUD VOLCANOES IN ACADEMICIAN RIDGE, LAKE BAIKAL
}

\author{
0. M. Khlystov ${ }^{1}$, H. Minami², A. Hachikubo², S. Yamashita ${ }^{2}$, \\ M. De Batist ${ }^{3}$, L. Nauds ${ }^{3}{ }^{4}$, A. V. Khabuev ${ }^{1}$, A. G. Chenskiy ${ }^{5}$, \\ N. A. Gubin ${ }^{5}$, S. S. Vorobyeva ${ }^{1}$ \\ ${ }^{1}$ Limnological Institute, Siberian Branch of RAS, Irkutsk, Russia \\ ${ }^{2}$ Environmental and Energy Resources Research Center, Kitami Institute of Technology, Kitami, Japan \\ ${ }^{3}$ Renard Centre of Marine Geology (RCMG), University of Ghent, Ghent, Belgium \\ ${ }^{4}$ Royal Belgian Institute of Natural Sciences - Operational Directorate Natural Environment \\ (RBINS - OD Nature), Oostende, Belgium \\ ${ }^{5}$ Irkutsk National Research Technical University, Russia
}

Abstract: Lake Baikal is the only freshwater reservoir on Earth with gas-hydrate accumulations in its bottom sediments, partly due to the activity of mud volcanoes. This paper describes a group of mud volcanoes recently discovered on the slope of the Academician Ridge between the northern and central Lake Baikal basins. Our analysis of diatom skeletons in the mud breccia sampled from the study area shows a high abundance of Cyclotella iris et var. These extinct species were also discovered in a core sample from BDP-98 borehole. Based on the biostratigraphic and seismostratigraphic correlations, the age of the mud breccia in the studied mud volcanoes ranges from the Late Miocene to the Early Pliocene (4.6 to $5.6 \mathrm{Ma}$ ). The correlations suggest that the material originated from a depth of less than $310 \mathrm{~m}$ below the lake bottom.

Key words: mud volcano; mud volcanic breccia; gas hydrate; diatom analysis; biostratigraphy; seismic stratigraphy; Lake Baikal

\section{RESEARCH ARTICLE}

Recommended by K.Zh. Seminsky
Received: April 24, 2017

Revised: May 15, 2017

Accepted: June 13, 2017

For citation: Khlystov O.M., Minami H., Hachikubo A., Yamashita S., De Batist M., Nauds L., Khabuev A.V., Chenskiy A.G., Gubin N.A., Vorobyeva S.S., 2017. Age of mud breccia from mud volcanoes in Academician Ridge, Lake Baikal. Geodynamics \& Tectonophysics 8 (4), 923-932. doi:10.5800/GT-2017-8-4-0324.

Для цитирования: Хлыстов О.М., Минами Х., Хачикубо А., Ямашита С., Де Батист М., Наудс Л., Хабуев А.В., Ченский А.Г., Губин Н.А., Воробьева С.С. Возраст грязевой брекчии грязевых вулканов Академического хребта озера Байкал // Геодинамика и тектонофизика. 2017. Т. 8. № 4. С. 923-932. doi:10.5800/GT-2017-8-4-0324. 


\title{
ВОЗРАСТ ГРЯЗЕВОЙ БРЕКЧИИ ГРЯЗЕВЫХ ВУЛКАНОВ АКАДЕМИЧЕСКОГО ХРЕБТА ОЗЕРА БАЙКАЛ
}

\author{
О. М. Хлыстов ${ }^{1}$, Х. Минами², А. Хачикубо르, С. Ямашита², \\ М. Де Батист ${ }^{3}$, Л. Наудс ${ }^{3,4}$, А. В. Хабуев ${ }^{1}$, А. Г. Ченский ${ }^{5}$, \\ Н. А. Губин ${ }^{5}$, С. С. Воробьева ${ }^{1}$ \\ 1 Лимнологический институт СО РАН, Иркутск, Россия \\ ${ }^{2}$ Исследовательский центр окружающей среды и источников энергии, Технологический \\ институт Китами, Китами, Япония \\ ${ }^{3}$ Центр морской геологии им. Ренарда, Университет Гента, Гент, Бельгия \\ ${ }^{4}$ Королевский бельгийский институт естественных наук, Управление окружающей среды, \\ Остенде, Бельгия \\ ${ }^{5}$ Иркутский национальный исследовательский технический университет, Иркутск, Россия
}

\begin{abstract}
Аннотация: Озеро Байкал является единственным пресноводным водоемом, в донных отложениях которого обнаружены скопления газовых гидратов, часть из них связана с деятельностью грязевых вулканов. В настоящей работе представлена группа грязевых вулканов, обнаруженных с помощью съемки многолучевым эхолотом на склоне подводной возвышенности Академический хребет между средней и северной котловинами озера Байкал. Анализ скелетов диатомей в грязевой брекчии выявил в массе вымерший вид Cyclotella iris et var., который ранее был обнаружен в керне скважины BDP-98. При помощи биостратиграфической и сейсмостратиграфической корреляции было установлено, что материал, входящий в грязевую брекчию исследуемых грязевых вулканов, имеет возрастной интервал от позднего миоцена до раннего плиоцена (от 5.6 до 4.6 млн лет) и мог быть поднят с глубины не более 310 м ниже дна.
\end{abstract}

Ключевые слова: грязевой вулкан; грязевая брекчия; газовый гидрат; диатомовый анализ; биостратиграфия; сейсмостратиграфия; озеро Байкал

\section{1. ВВЕДЕНИЕ}

Грязевые вулканы являются естественными скважинами в глубокозалегающих осадочных отложениях, и в их грязевых потоках содержится материал далекого прошлого. Сами грязевые вулканы в Мировом океане чаще всего связаны с зонами подводных конусов выноса, сдвиговых поясов, надвигов, взбросов, т.е. с районами распространения многокилометровых осадочных толщ и доминирования условий сжатия. Нередко они расположены над нефтегазовыми месторождениями - зонами с избыточным давлением флюидов и газа. Наличие грязевого вулканизма во впадине озера Байкал, т.е. в пределах формирующейся при растяжении Байкальской рифтовой зоны, может быть свидетельством этапов локального сжатия в истории развития рифта или его отдельных элементов при сдвигах, взбросах по второстепенным или основным разломам. Открытия и исследования подводных грязевых вулканов на дне озера Байкал непосредственно связаны с изучением газовых гидратов в его осадках, впервые описанных в 1997 г. в буровом керне на поддонной глубине 121 и 161 м
[Kuz'min et al., 1998], а в 2000 г. - в приповерхностных (0.5 м) осадках [Klerkx et al., 2003]. Впервые предположение о наличии грязевых вулканов было высказано на основе лишь батиметрических данных, где ряд крупных подводных возвышенностей, включая Посольскую банку, был отнесен к вероятным грязевым вулканам [Isaev, 2001]. Однако в результате комплексного анализа батиметрических и геофизических данных это не подтвердилось, но были обнаружены первые грязевые вулканы в Южном Байкале при анализе других, более мелких, подводных возвышенностей [Van Rensbergen et al., 2002; De Batist et al., 2002]. Геологическим доказательством существования грязевого вулканизма стали находки грязевой брекчии в этих структурах [Khlystov, 2006]. Как в геологическом, так и в геофизическом аспекте грязевые вулканы озера Байкал не обладают рядом характеристик, часто относимых к морским грязевым вулканам, как, например, современные грязевые потоки, кальдеры вокруг кратера, а также древовидный канал на сейсмических данных. С другой стороны, все структуры имели положительную форму в виде холмов разного размера на ровном дне озера, немую запись на 
сейсмоакустических профилях под ними и газовые гидраты у поверхности. Это обусловливалось выносом грязевого газонасыщенного материала из нижележащих осадочных толщ на поверхность дна вдоль разлома при разгрузке газонасыщенного флюида [Van Rensbergen et al., 2002; De Batist et al., 2002; Cuylaerts et al., 2012].

Поиск гидратоносных структур на Байкале первоначально велся только в областях наличия BSR (Bottom Simulation Reflector - косвенный геофизический признак наличия газовых гидратов), т.е. вокруг авандельты р. Селенги и части центральной котловины, где он был обнаружен на сейсмических профилях [Golmshtok et al., 1997]. В результате в этой области дна озера были открыты сипы, покмарк и грязевые вулканы, всего 21 гидратоносная структура. Грязевые вулканы представляли собой одиночные положительные поднятия на ровном дне или пологом склоне, за исключением группы грязевых вулканов района Кукуйского каньона, и были связаны с разрывными нарушениями [Сuуlaerts et al., 2012; Khlystov et al., 2013]. Позже по данным одноканального и многоканального сейсмопрофилирования BSR был также выделен практически по всей южной и средней котловинам, включая юго-восточный блок Академического хребта [Casier et al., 2010]. Благодаря новой батиметрической съемке дна южной и средней котловин многолучевым эхолотом (МЛЭ) были идентифицированы новые гидратоносные структуры (дополнительно 23), в том числе грязевые вулканы разных форм и размеров. Однако геологические и геофизические сведения не позволили оценить ни возраст грязевого материала, ни глубину корней грязевых вулканов в этих котловинах. Отметим, что для морских грязевых вулканов глубина грязевого источника может достигать первых километров, а возраст пород, слагающих грязевулканическую брекчию, варьироваться от мела до плиоцена [Kholodov, 2002].

В настоящей работе мы описываем новую грязевулканическую гидратоносную область озера Байкал, расположенную в районе, где признаки нахождения грязевых вулканов или газовых гидратов прежде не регистрировались: подводная возвышенность Академический хребет, расположенная между Средней и Северной впадинами, между о. Ольхон и о. Большой Ушканий. В этом районе ранее проводились комплексные работы по изучению строения, истории развития данной части озера и палеоклимата, включая глубоководное бурение (BDP-96 и ВDP-98). Это позволило подробно описать стратиграфические последовательности и получить опорный разрез для этой части озера [Zonenshain et al., 1995; Kaz'min et al., 1995; Moore et al., 1997; Baikal Drilling Project Group, 2000; Khlystov et al., 2000, 2001; Mats et al., 2000].

\section{2. МАТЕРИАЛЫ И МЕТОДЫ}

Для поиска и исследования грязевых вулканов на Академическом хребте использовались данные МЛЭ, полученные в 2009 и 2016 гг. на борту НИС «Г. Титов», а также геологический и биостратиграфический анализ осадочных кернов, отобранных в 2013-2014 гг. с борта НИС «Г.Ю. Верещагин».

Батиметрические данные получены МЛЭ ELAC SeaBeam 1050 и Konengsberg EM710S. Первый давал разрешение $1.5 \times 1.5$ м на глубине $\sim 50$ м и $37 \times 37$ м на глубине 1500 м (ширина диаграммы направленности $3 \times 3^{\circ}$ ). Съемка этим эхолотом охватила всю площадь подводного Академического хребта [Cuylaerts et al., 2012] и по разрешению в четыре раза превосходила ранее имеющиеся батиметрические данные по Байкалу. Второй эхолот позволял получать батиметрические параметры по вертикали с разрешением первые сантиметры, а по горизонтали - первые метры, что еще в два раза улучшило разрешение данных.

Осадочные керны были получены с помощью гравитационных прямоточных труб длиной от 3 до 5 м, весом от 500 до 800 кг. Отбор проб на геологические и биостратиграфические анализы велся на борту судна из интервалов керна с грязевулканической брекчией. Диатомовый анализ проводился в пробах из керна VER-14-03-9GC12 (N 53.4731; $\mathrm{E} 108.0853^{\circ}$ ) в интервале 70-220 см по стандартной методике, описанной в работе [Grachev et al., 1997].

\section{3. РезУЛЬТАТЫ}

Анализ новейших батиметрических данных по данным МЛЭ выявил на южном склоне юго-восточного блока Академического хребта две поперечные хребту структуры, состоящие из нескольких кратеров и холмов, слитых в гряды. Гряда в средней части хребта получила название «АкадемХребет», около о. Ольхон - «Хобой» (рис. 1). Ширина каждой из гряд не превышает 800 м. Они вытянуты в длину соответственно на 6 и 4 км. Гряда «АкадемХребет» расположена на глубине 500-850 м, а «Хобой» - 450-600 м. Высота гряд не превышает 80 м. Наиболее выразительна в рельефе гряда «АкадемХребет». Она состоит из двух частей, сочленяющихся под углом друг к другу и разделенных понижением на глубине 650-680 м. Мелководная часть гряды (500-600 м) имеет крутые углы падения и ориентирована по азимуту $140^{\circ}$, состоит из узкого гребня длиной 1.2 км и шириной до 200 м, постепенно расширяясь до 400 м на протяжении следующего 1 км. В широкой части расположены четыре крупных кратера с плоским дном диаметром от 150 до 250 м, идущие друг за другом вниз по склону. 


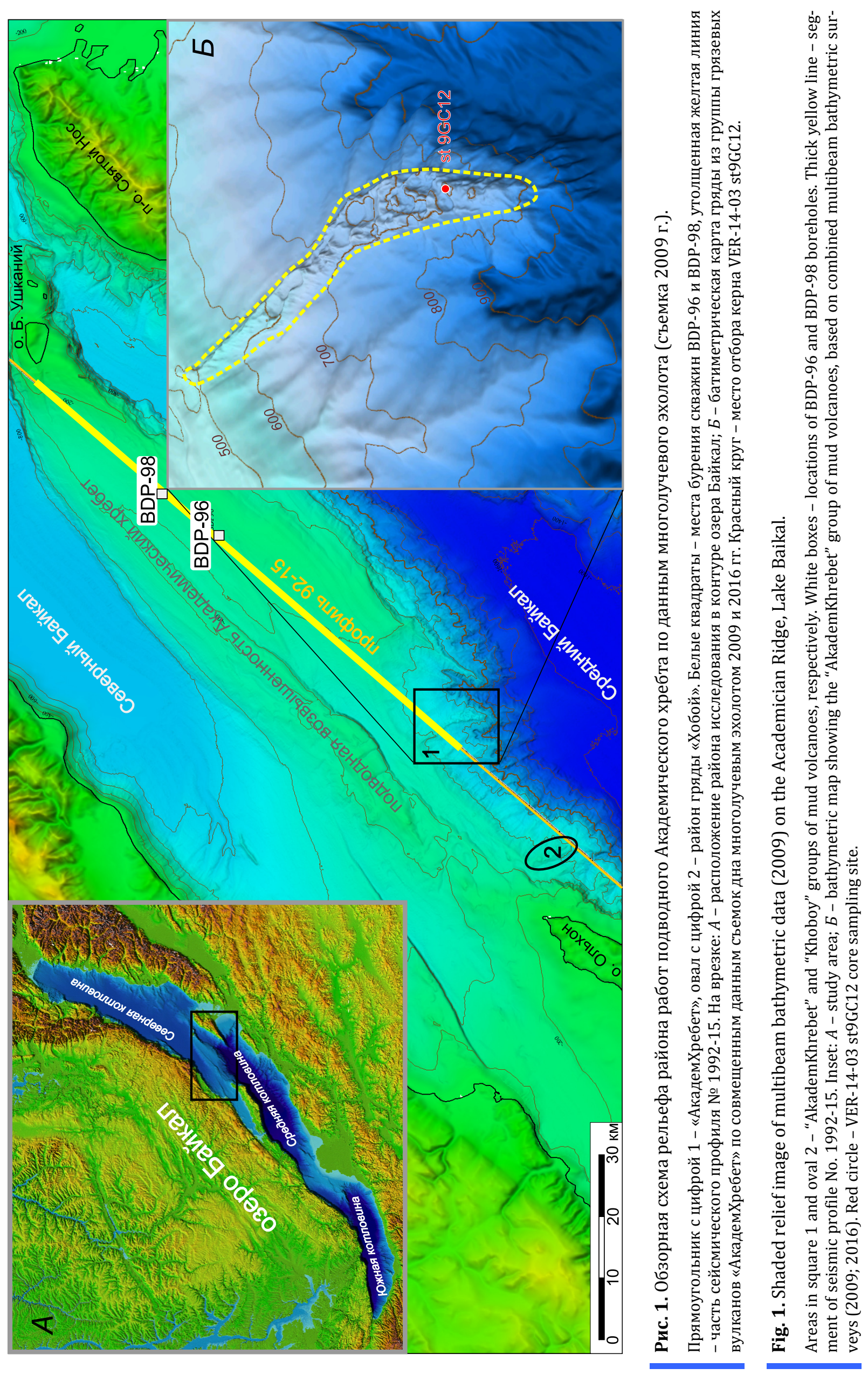




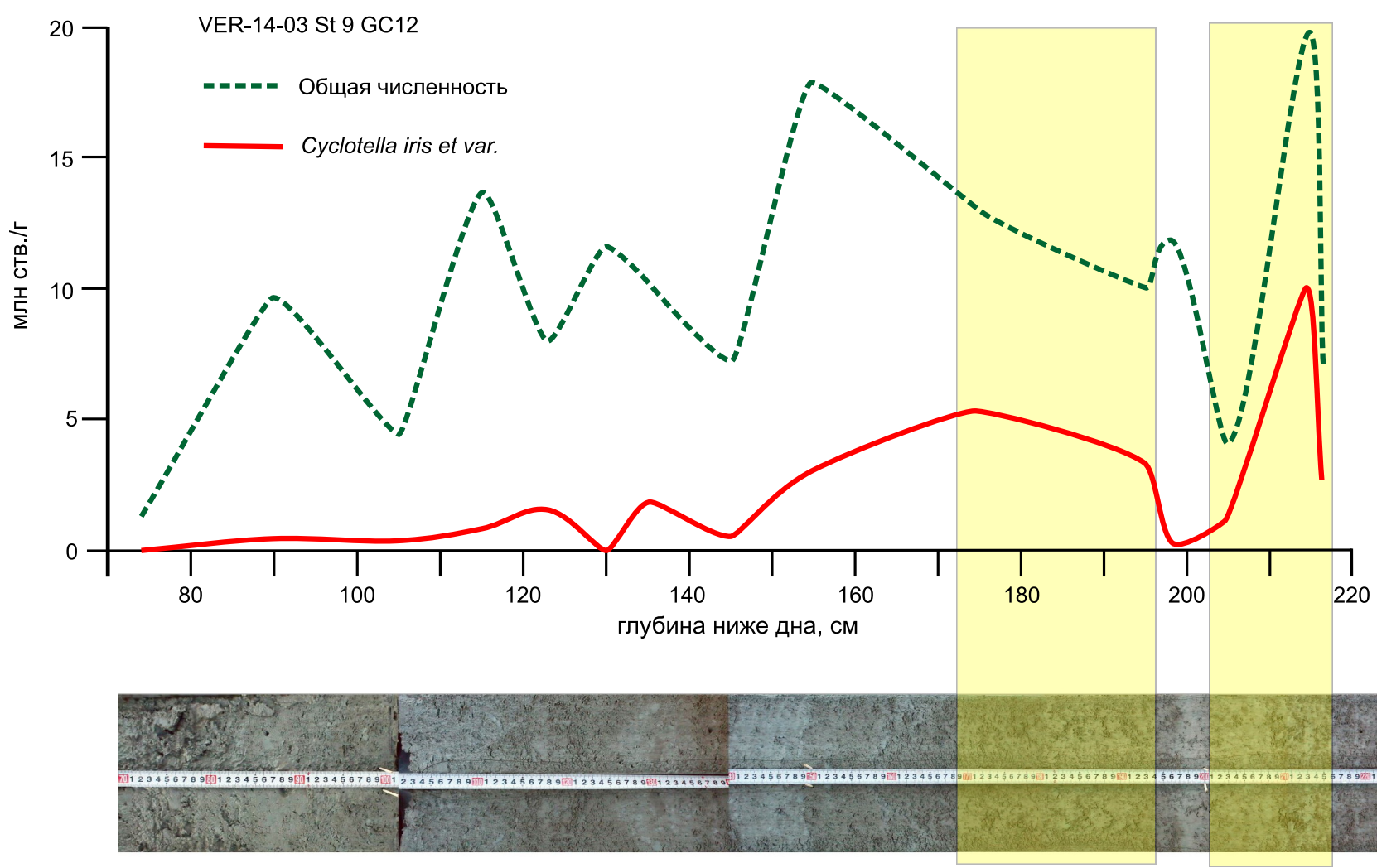

Рис. 2. Распределение диатомовых водорослей ископаемого вида Cyclotella iris et var. и общей численности всех видов диатомей в интервале с грязевулканической брекчией. Желтые прямоугольники указывают на горизонты с максимальным количеством древнего вида (51 \% от общей численности).

Fig. 2. Distribution of diatoms of the fossil species Cyclotella iris et var. and the total number of all diatom species within the interval with mud volcanic breccias. Yellow rectangles - horizons with the maximum amount of the ancient species $(51 \%$ of the total number).

Более глубоководная часть гряды (680-850 м) имеет практически субмеридиональное простирание на протяжении более 3 км, ширина гряды в средней части достигает 800 м. Эта часть гряды состоит из кратеров и возвышенностей, слитых друг с другом. Первый из кратеров, с севера на юг, имеет максимальный диаметр 300 м, относительно плоское дно. Он соединен с двумя более мелкими кратерами. Далее вниз по склону идут три разных по размеру кратера, разделенных между собой холмами и грядами высотой до 30 м. Внутри одного из кратеров есть возвышенность высотой до 20 м. В конце гряды также есть холм высотой 20 м и в диаметре 250 м, не связанный с кратерами (рис. 1).

Геологическое опробование осуществлено по всей гряде «Хобой» и глубоководной части гряды «АкадемХребет». Практически во всех кернах из обеих гряд на холмах и склонах кратеров встречена грязевая брекчия в виде разноразмерных глинистых плотных включений светло-серого цвета в мягкой оливково-серой глинистой матрице. Она всегда была перекрыта слоем разжиженного диатомового ила голоценового возраста мощностью от
0.7 до 3.0 м. В некоторых из кернов обнаружены слои газовых гидратов.

Отбор проб на диатомовый анализ осуществлялся из интервала керна с грязевой брекчией, полученного из возвышенности на краю самого нижнего кратера гряды «АкадемХребет» на глубине 710 м (рис. 1). Анализ проб показал, что в них присутствует 88 видов и разновидностей диатомовых водорослей (45 планктонных таксонов и 43 - бентосных). Их численность достигает 0.6-19.4 млн створок на 1 грамм сухого осадка (млн ств./г). Пробы содержали 32 таксона древних вымерших видов. Преобладала Cyclotella iris и ее разновидности, с численностью до 10.1 млн ств./г, т.е. 51 \% от общей численности (рис. 2). В верхней части разреза до 70 см присутствовали диатомовые водоросли, характерные для голоценового комплекса.

\section{4. ОБСУЖДЕНИЕ}

Наличие в разрезе грязевой брекчии указывает на то, что эти гряды состоят из различных по раз- 
0.0

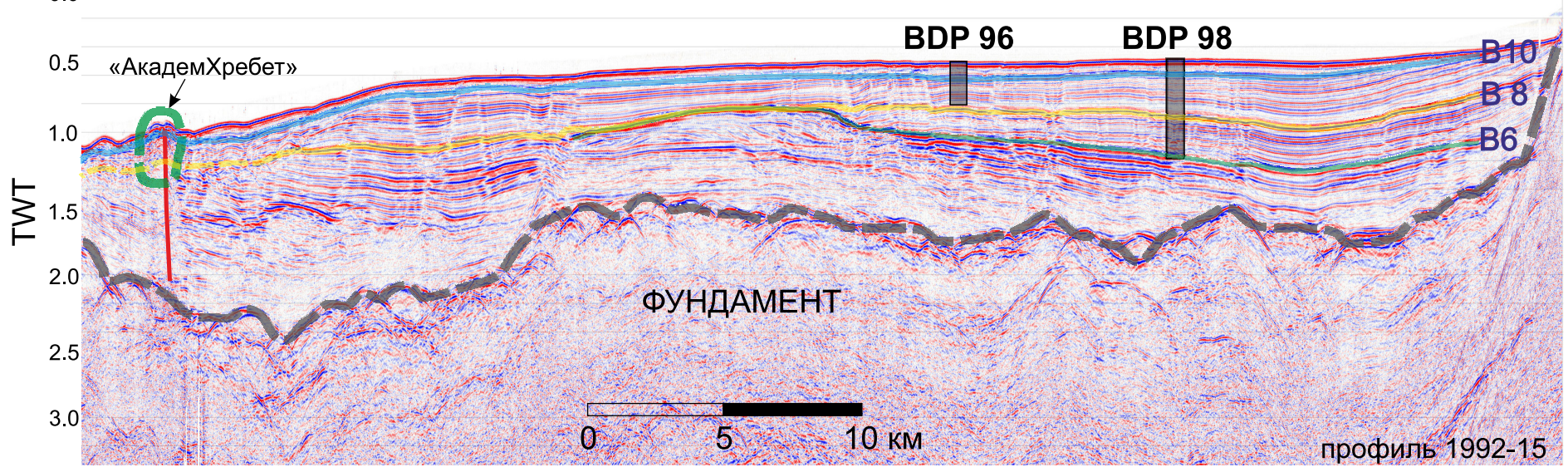

Рис. 3. Сейсмический профиль 1992-15 (по [Moore et al., 1997] с дополнениями). Голубая, серая и зеленая линии сейсмостратиграфические границы В10, В8 и В6. Красная вертикальная линия - разлом. Серый пунктир - граница акустического фундамента и слоистых осадочных толщ.

Fig. 3. Seismic profile No. 1992-15 (modified after [Moore et al., 1997]). Blue, grey and green lines - seismostratigraphic boundaries B10, B8 and B6. Grey dashed line - boundary between the acoustic basement and the stratified sedimentary rocks. Red vertical line - fault.

мерам грязевых вулканов. Наиболее крупные из них имеют кратеры, более мелкие представляют собой холмы. Все грязевые вулканы не активны в настоящее время, так как перекрыты голоценовым слоем диатомового ила, но в разрезе еще сохраняются слои газовых гидратов, что говорит о достаточном насыщении отложений газом, а значит, о постепенном его подтоке из нижних слоев по газовым и грязевулканическим каналам. Кроме того, это также указывает на отсутствие, по крайней мере в период накопления диатомового ила (10-12 тыс. лет), тектонической активности и условий сжатия в этом районе.

Анализ сейсмического профиля 1992 г. № 15, секущего гряду из грязевых вулканов «АкадемХребет» и проходящего через точки бурения BDP-96 и BDP-98, указывает на наличие одних и тех же сейсмокомплексов и сейсмических границ (B10 и B8) в обоих районах и на наличие разлома под грязевыми вулканами (рис. 3). Возможно, гряда из грязевых вулканов маркирует поперечный разлом между основными продольными сбросами Академического хребта, вдоль которого шло ее формирование. Граница В8 располагается на глубине 270 м, а в районе грязевых вулканов «АкадемХребет»- на глубине 250 м ниже дна и на всем протяжении между этими районами не имеет перерывов. Соответственно мы можем предположить идентичный геологический разрез этих районов, а с помощью биостратиграфической корреляции по составу диатомовых створок оценить возраст материала, из которого состоит грязевая брекчия. Диатомовый анализ показал преобладание в этой брекчии вблизи поверхности дна древнего вымершего вида Cyclotella iris и ее разновидностей, которые были определены ранее в разрезе скважины глубоководного бурения BDP-98 в интервале 230-310 м ниже дна. В этом же интервале, на 270-метровом горизонте, также находится граница B8, связанная с изменением литологических свойств и физических параметров осадка, а не с перерывами в осадконакоплении [Baikal Drilling Project Group, 2000]. Возраст этой части бурового керна оценивается как позднемиоценовый - раннеплиоценовый (5.64.6 млн лет) [Kuz'min et al., 2009]. Исходя из того, что граница B8 не является тектоническим несогласием и примерно совпадает по глубине в обоих районах, а состав диатомовых комплексов и донных отложений должен быть идентичным, мы можем предположить, что материал, из которого сложен один из грязевых вулканов «АкадемХребет», был поднят с глубин, где проходит сейсмическая граница В8 (250 м), но не глубже 310 м, где находится нижняя граница слоя с диатомовыми водорослями Cyclotella iris et var. по данным бурения.

Таким образом, методами сейсмостратиграфической и биостратиграфической корреляции разреза керна скважины BDP-98 с разрезом донных отложений района группы грязевых вулканов «АкадемХребет» установлено, что грязевулканическая брекчия поднята на поверхность дна с поддонной глубины не более 310 м, а входящий в ее состав материал не моложе раннего плиоцена и не древнее позднего миоцена. 


\section{5. ЗАКЛЮЧЕНИЕ}

Биостратиграфическим методом определен возраст материала, слагающего грязевую брекчию грязевых вулканов гряды «АкадемХребет», в интервале от 4.6 до 5.6 млн лет. Он идентичен возрасту донных отложений на глубине 230-310 м в точке бурения BDP-98, внутри которых проходит сейсмостратиграфическая граница В8 (270 м). Таким образом, впервые вещественно определен возраст (поздний миоцен - ранний плиоцен) и оценена максимальная глубина корней (310 м) байкальских грязевых вулканов на Академическом хребте.

Столь неглубокое заложение корней грязевого вулкана поможет в будущем объяснить причины и механизмы образования грязевых вулканов озера Байкал, а также аномальность в морфологии и строение байкальских грязевых вулканов по сравнению с морскими. Отсутствие современных, свежих грязевых потоков и присутствие во всех кернах диатомового слоя голоценового возраста по- верх грязевой брекчии указывают на отсутствие активности грязевых вулканов в последние 1012 тыс. лет, а значит, и условий сжатия в зоне близлежащих разломов на Академическом хребте.

\section{6. БЛАГОДАРНОСТИ}

Работа выполнена при финансовой поддержке проектов № 0345-2016-0007 (анализ геологических и биологических данных) и № 345-2015-0026 (обработка и анализ батиметрических данных), полевые работы - за счет проектов Президиума РАН 17.8 (2009) и FWO Flanders project 1.5.198.09, грантов японского общества содействия науке (JSPS) KAKENHI JP24404026 (to H.M.), JP26303021 (to A.H.), JP16H05760 (to H.M.) и президентского гранта Института технологий Китами. Авторы выражают благодарность капитанам и экипажам научноисследовательских судов ЛИН СО РАН «Г.Ю. Верещагин» и «Г. Титов».

\section{7. ЛИТЕРАTУРA / REFERENCES}

Baikal Drilling Project Group. Antipin V., Afonina T., Badalov O., Bezrukova E., Bukharov A., Bychinskii V., Williams D., Gvozdkov A., Geletii V., Golubev V., Goreglyad A., Gorokhov I., Dmitriev A., Dorofeeva R., Duchkov A., Esipko O., Ivanov E., Yoshida N., Kawai T., Kalashnikova I., Kalmychkov G., Karabanov E., Kerber E., King J., Konstantinov K., Kochukov V., Kravchinskii V., Krainov M., Kukhar' L., Kudryashov N., Kuz'min M., Nakamura K., Nomura S., Oxenoid E., Pevsner L., Peck J., Prokopenko A., Romashov V., Sakai H., Sandimirov I., Sapozhnikov A., Seminskii K., Soshina N., Tkachenko L., Ushakovskaya M., Fileva T., Khakhaev B., Khlystov O., Khuzin M., Hursevich G., 2000. Late Cenozoic paleoclimate record in bottom sediments of Lake Baikal (600 m deep drilling data). Geologiya i Geofizika (Russian Geology and Geophysics) 41 (1), 1-29.

Casier R., Naudts L., Cuylaerts M., Khlystov O., De Batist M., 2010. Reassessment of gas hydrate occurrences in Lake Baikal based on the analysis of BSRs on 180 seismic reflection profiles and on the identification of submarine landslides. In: Book of abstracts of the 10th International Conference on gas in marine sediments. Listvyanka (Lake Baikal), Russia, p. 95-96.

Cuylaerts M., Naudts L., Casier R., Khabuev A.V., Belousov O.V., Kononov E.E., Khlystov O., De Batist M., 2012. Distribution and morphology of mud volcanoes and other fluid flow-related lake-bed structures in Lake Baikal, Russia. Geo-Marine Letter 32 (5-6), 383-394. https://doi.org/10.1007/s00367-012-0291-1.

De Batist M., Klerkx J., Van Rensbergen P., Vanneste M., Poort J., Golmshtok A., Kremlev A., Khlystov O., Krinitsky P., 2002. Active hydrate destabilization in Lake Baikal, Siberia. Terra Nova 14 (6), 436-442. https://doi.org/10.1046/ j.1365-3121.2002.00449.x.

Golmshtok A.Y., Duchkov A.D., Hutchinson D.R., Khanukaev S.B., Elnikov A.I., 1997. Estimations of heat flow on Baikal from seismic data on the lower boundary of the gas hydrate layer. Geologiya i Geofizika (Russian Geology and Geophysics) 38 (10), 1677-1691.

Grachev M.A., Likhoshway E.V., Vorobieva S.S., Khlystov O.M., Bezrukova A.V., Veinberg E.V., Goldberg E.L., Granina L.Z., Kornakova E.G., Lazo F.I., Levina O.V., Letunova P.P., Otinov P.V., Pirog V.V., Fedotov A.P., Yaskevich A.V., Bobrov V.A., Sukhorukov F.V., Rezchikov V.I., Fedorin M.A., Zolotarev K.V., Kravchinsky V.A., 1997. Signals of the paleoclimates of Upper Pleistocene in the sediments of Lake Baikal. Geologiya i Geofizika (Russian Geology and Geophysics) 38 (5), 994-1018.

Isaev V.P., 2001. On the gas paleovolcanism on Lake Baikal. Geologiya Nefti i Gaza (Geology of Oil and Gas) (5), 45-50 (in Russian) [Исаев В.П. О газовом палеовулканизме на Байкале // Геология нефти и газа. 2001. № 5. C. 45-50].

Kaz'min V.G., Gol'mshtok A.Ya., Klitgord K.D., Moore T., Hutchinson D., Scholz C., Weber E., 1995. Structure and development of the Akademichesky Ridge area (Baikal rift) according to seismic investigations. Geologiya i Geofizika (Russian Geology and Geophysics) 36 (10), 164-176 (in Russian) [Казьмин В.Г., Гольмшток А.Я., Клитгорд К., Мур Т., Хатчинсон Д., Шольц С., Вебер Е. Строение и развитие района Академического хребта по данным сейсмических и подводных исследований (Байкальский рифт) // Геология и геофизика. 1995. Т. 36. № 10. C. 164-176]. 
Khlystov O.M., 2006. New findings of gas hydrates in the Baikal bottom sediments. Geologiya i Geofizika (Russian Geology and Geophysics) 47 (8), 979-981.

Khlystov O.M., De Batist M., Shoji H., Hachikubo A., Nishio S., Naudts N., Poort J., Khabuev A., Belousov O.M., Manakov A.Y., Kalmychkov G.V., 2013. Gas hydrate of Lake Baikal: Discovery and varieties. Journal of Asian Earth Sciences 62, 162-166. https://doi.org/10.1016/j.jseaes.2012.03.009.

Khlystov O.M., Mats V.D., De Batist M., 2001. The southwestern edge of the North Baikal basin: Geologic structure and correlation with Cenozoic sections of Ol'khon and BDP-96 and BDP-98 cores. Geologiya i Geofizika (Russian Geology and Geophysics) 42 (1-2), 373-383.

Khlystov O.M., Mats V.D., Vorob'eva S.S., Klimanskii A.V., De Batist M., Ceramicola S., 2000. Structure and evolution of the underwater Akademichesky Ridge (Lake Baikal). Geologiya i Geofizika (Russian Geology and Geophysics) 41 (6), 819-824.

Kholodov V.N., 2002. On the origin of mud volcanos. Priroda (Nature) (11), 47-58 (in Russian) [Холодов В.Н. 0 природе грязевых вулканов // Природа. 2002. № 11. С. 47-58].

Klerkx J., Zemskaya T.I., Matveeva T.V., Khlystov O.M., Namsaraev B.B., Dagurova O.P., Golobokova L.P., Vorob'eva S.S., Pogodaeva T.P., Granin N.G., Kalmychkov G.V., Ponomarchuk V.A., Shoji H., Mazurenko L.L., Kaulio V.V., Solov'ev V.A., Grachev M.A., 2003. Methane Hydrates in Deep Bottom Sediments of Lake Baikal. Doklady Earth Sciences 393 (9), 1342-1346.

Kuz'min M.I., Kalmychkov G.V., Geletii V.F., Gnilusha V.A., Goreglyad A.V., Khakhaev B.N., Pevzner L.A., Kawai T., Yoshida N., Duchkov A.D., Ponomarchuk V.A., Kontorovich A.E., Bazhin N.M., Makhov G.A., Dyadin Yu.A., Kuznetsov F.A., Larionov E.G., Manakov A.Yu., Smolyakov B.S., Mandel'baum M.M., Zheleznyakov N.K., 1998. The first find of gas-hydrates in the sedimentary rocks of Lake Baikal. Doklady Earth Sciences 362 (7), 1029-1031.

Kuz'min M.I., Khursevich G.K., Prokopenko A.A., Fedenya S.A., Karabanov E.B., 2009. Centric Diatom Algae of Baikal in the Late Cenozoic: Morphology, Systematics, Stratigraphic Occurrence, and Stages of Evolution (from Deep-Water Drilling Data). "Geo" Publishing House, Novosibirsk, 374 p. (in Russian) [Кузьмин М.И., Хурсевич Г.К., Прокопенко А.А., Феденя С.А., Карабанов Е.Б. Центрические диатомовые водоросли позднего кайнозоя озера Байкал: морфология, систематика, стратиграфическое распространение, этапность развития (по материалам глубоководного бурения). Новосибирск: Академическое изд-во «Гео», 2009. 374 с.].

Mats V.D., Khlystov O.M., De Batist M., Ceramicola S., Lomonosova T.K., Klimansky A., 2000. Evolution of the Academician Ridge accommodation zone in the central part of the Baikal Rift, from high-resolution reflection seismic profiling and geological field investigations. International Journal of Earth Sciences 89 (2), 229-250. https://doi.org/ $10.1007 / \mathrm{s} 005310000094$.

Moore Jr. T.C., Klitgord K.D., Golmshtok A.J., Weber E., 1997. Sedimentation and subsidence patterns in the central and north basins of Lake Baikal from seismic stratigraphy. Geological Society of America Bulletin 109 (6), 746-766. https://doi.org/10.1130/0016-7606(1997)109<0746:SASPIT>2.3.CO;2.

Van Rensbergen P., De Batist M., Klerkx J., Hus R., Poort J., Vanneste M., Granin N., Khlystov O., Krinitsky P., 2002. Sublacustrine mud volcanoes and methane seeps caused by dissociation of gas hydrates in Lake Baikal. Geology 30 (7), 631-634. https://doi.org/10.1130/0091-7613(2002)030<0631:SMVAMS>2.0.C0;2.

Zonenshain L.P., Kaz'min V.G., Kuz'min M.I., 1995. New data on the Baikal history: observations from manned submersibles. Geotektonika (Geotectonics) (3), 46-58 (in Russian) [Зоненшайн Л.П., Казьмин В.Г., Кузьмин М.И. Новые данные по истории Байкала: результаты наблюдений с подводных обитаемых аппаратов // Геотектоника. 1995. № 3. С. 46-58].

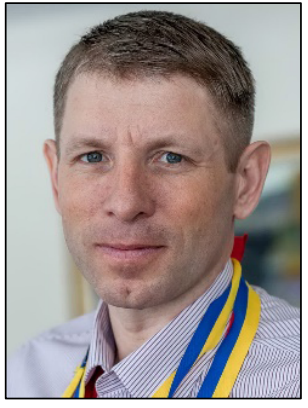

Хлыстов Олег Михайлович, зав. лабораторией

Лимнологический институт СО РАН

664033, Иркутск, ул. Улан-Баторская, 3, Россия

e-mail: oleg@lin.irk.ru

Khlystov, Oleg M., Head of Laboratory

Limnological Institute, Siberian Branch of RAS

3 Ulan-Batorskaya street, Irkutsk 664033, Russia

e-mail: oleg@lin.irk.ru 

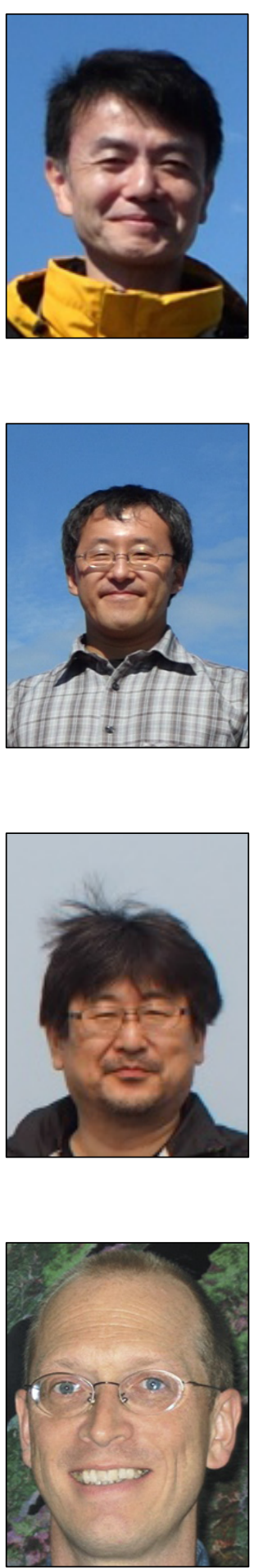

Марк Де Батист, доктор, профессор, директор департамента Центр морской геологии им. Ренарда, Университет Гента, Гент, Бельгия Campus Sterre, Building S8, Krijgslaan 281, B-9000 Ghent, Belgium e-mail: marc.debatist@ugent.be

De Batist, Marc, PhD, Professor, Head of Department Renard Centre of Marine Geology (RCMG), Ghent University Campus Sterre, Building S8, Krijgslaan 281, B-9000 Ghent, Belgium e-mail: marc.debatist@ugent.be

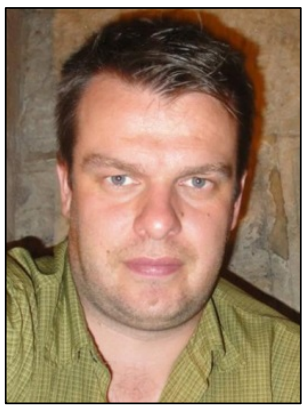

Ливен Наудс, доктор, начальник отдела измерений, координатор НИС «Бельгия» Центр морской геологии им. Ренарда, Университет Гента, Гент, Бельгия

Campus Sterre, Building S8, Krijgslaan 281, B-9000 Ghent, Belgium

Королевский бельгийский институт естественных наук, Управление окружающей среды, Остенде, Бельгия

3de en 23ste Linieregimentsplein, B-8400 Oostende, Belgium e-mail: Lieven.Naudts@naturalsciences.be

Naudts, Lieven, PhD, Coordinator of RV Belgica, Head Measurement Services Ostend (MSO) Renard Centre of Marine Geology (RCMG), Ghent University

Campus Sterre, Building S8, Krijgslaan 281, B-9000 Ghent, Belgium

Royal Belgian Institute of Natural Sciences (RBINS)

3de en 23ste Linieregimentsplein, B-8400 Oostende, Belgium

e-mail: Lieven.Naudts@naturalsciences.be 

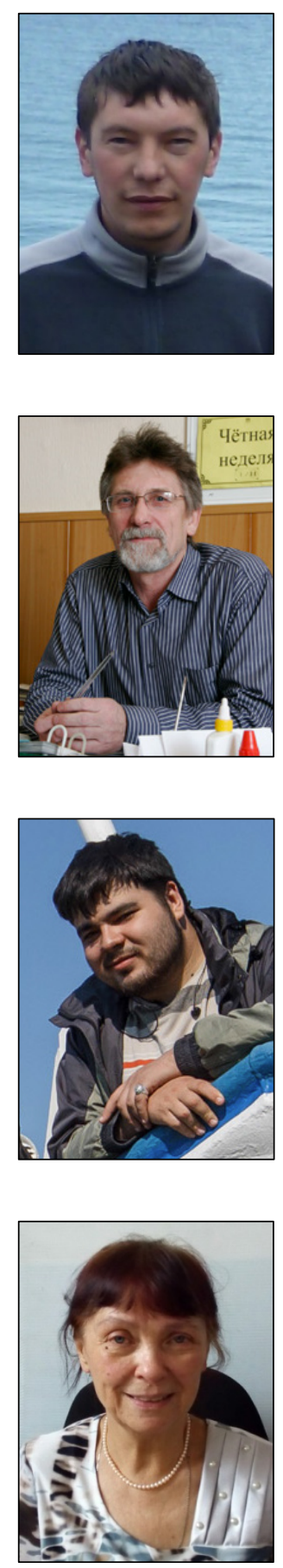

Хабуев Андрей Владимирович, ведущий инженер

Лимнологический институт СО РАН

664033, Иркутск, ул. Улан-Баторская, 3, Россия

e-mail: shock@lin.irk.ru

Khabuev, Andrei V., Lead Engineer

Limnological Institute, Siberian Branch of RAS

3 Ulan-Batorskaya street, Irkutsk 664033, Russia

e-mail: shock@lin.irk.ru

Ченский Александр Геннадьевич, канд. физ.-мат. наук, зав. кафедрой радиоэлектроники и телекоммуникационных систем

Иркутский национальный исследовательский технический университет

664074, Иркутск, ул. Лермонтова 83, Россия

e-mail: chens-01@yandex.ru

Chenskiy, Aleksander G., Candidate of Physics and Mathematics, Chair of Radioelectronics and Telecommunication Systems

Irkutsk National Research Technical University

83 Lermontov street, Irkutsk 664074, Russia

e-mail: chens-01@yandex.ru

Губин Никита Андреевич, лаборант-исследователь

Иркутский национальный исследовательский технический университет 664074, Иркутск, ул. Лермонтова 83, Россия

e-mail: gubin.1@yandex.ru

Gubin, Nikita A., Laboratory Assistant Researcher Irkutsk National Research Technical University 83 Lermontov street, Irkutsk 664074, Russia e-mail: gubin.1@yandex.ru

Воробьева Светлана Семеновна, канд. биол. наук, с.н.с.

Лимнологический институт СО РАН

664033, Иркутск, ул. Улан-Баторская, 3, Россия

e-mail: lana@lin.irk.ru

Vorobyeva, Svetlana S., Candidate of Biology, Senior Researcher

Limnological Institute, Siberian Branch of RAS

3 Ulan-Batorskaya street, Irkutsk 664033, Russia

e-mail: lana@lin.irk.ru 